\title{
TINJAUAN HUKUM ISLAM TERHADAP PRAKTEK JUAL BELI SISTEM HUTANG HASIL PERTANIAN
}

\author{
Muhammad Ngasifudin, Tri Almunawaroh \\ STKIP Majenang \\ Email: ngasifudinelaziz@gmail.com,tri almun@yahoo.co.id
}

\begin{abstract}
This reserch aims to analyze agricultural trading on credit system in islamic approach. This research was conducted in the village of Pahonjean. Majenang towards the welfare of farmers. Data collection was carried out by observation, and interviews. By using a qualitative approach the results showed that this system of accounts receivable has become a habit among farmers and the impression from this system is that new farmers can only fulfill their primary and secondary needs.
\end{abstract}

Keywords: Buying and Selling, Islamic Law, Agriculture

Abstrak: $\quad$ Penelitian ini bertujuan untuk mengetahui tinjauan Hukum Islam terhadap praktik jual beli sistem hutang hasil pertanian di Desa Pahonjean Kecamatan Majenang terhadap kesejahteraan Petani. Penelitian ini termasuk dalam penelitian deskriptif dengan pendekatan Kualitatif . Pengumpulan data dilakukan dengan observasi dan wawancara. Hasil penelitian menunjukan bahwa sistem hutang piutang ini sudah menjadi adat kebiasaan di kalangan para petani dan efek dari sistem ini petani baru hanya bisa memenuhi kebutuhannya sebatas kebutuhan primer dan sekunder.

Kata kunci : Jual Beli, Hukum Islam, Pertanian

\section{A. PENDAHULUAN}

Berdasarkan studi Hardinawati ${ }^{1}$, pihak yang mau membeli hasil panen petani hanyalah tengkulak, Studi ${ }^{2}$ jual beli dengna sistem tebasan dilakukan dengan beberapa tahap di antaranya: pertama penjual akan menawarkan padi yang akan mereka jual kepada pembeli. Selanjutnya pembeli akan mendatangi atau mensurvei padi milik petani yang akan dijual dan melakukan beberapa perkiraan mengenai harga padi yang hampir siap panen dan melihat kualitas dari biji padi yang akan dibeli. Setelah disurvei akan dilakukan tawar menawar harga dengan penjual/ petani, kemudian jika keduanya sudah sepakat dengan harganya maka dilakukan perjanjian terhadap jual beli tersebut secara lisan dan menggunakan bahasa sehari-hari atau dengan menggunakan bahasa Using setelah itu pihak penebas memberi uang muka (panjer) sebagai tanda jadi dan sisanya dilunasi pada saat padi dipanen. Jual beli padi dengan sistem tebasan sudah menjadi kebisaaan yang sering dilakukan oleh masyarakat Dusun Kelir dengan maksud untuk mempermudah petani dalam proses penjualan padi yang siap panen, dan dengan harapan petani dapat mendapat uang secara cepat. karena jika petani menggunakan cara panen sendiri, akan menghabiskan banyak waktu dan biaya untuk keperluan panen dan pengolahannya

\footnotetext{
${ }^{1}$ Hardinawati Lusiana Ulfa, “Alasan Petani Muslim Menjual Hasil Panen Kepada Tengkulak Di Desa Glagahagung Kecamatan Purwoharjo Kabupaten Banyuwangi,” Skripsi : (Surabaya: Universitas Airlangga, 2017).

${ }^{2}$ Abdul Kholiq Syafa'at and Rohmatulloh, "Analisis Hukum Islam Terhadap Praktik Jual Beli Hasil Pertanian Padi Sistem Tebasan Di Dusun Kelir Desa Bunder Kecamatan Kabat Kabupaten Banyuwangi," Jurnal Darussalam; Jurnal Pendidikan, Komunikasi dan Pemikiran Hukum Islam X, no. 1 (2018), hlm.162-179.
} 
Penelitian yang dilakukan oleh Hardianto Eko, ${ }^{3}$ dalam studinya menjelaskan bahwa tengkulak juga berperan memberi modal kepada petani. Hal inilah yang membuat petani begitu tergantung pada tengkulak. Tengkulak di Dataran Tinggi Dieng dalam studi tersebut dijelaskan bahwa tengkulak memanfaatkan posisi sebagai pemberi modal pada petani. Hal tersebut digunakan tengkulak dalam mengikat petani agar terus menjual hasil panen kepadanya. Situasi yang digunakan tengkulak baik berupa panen raya atau bahkan saat gagal panen. Tengkulak sangat memanfaatkan masa masa gagal panen karena pada saat itu harga hasil panen anjlok dan petani kehabisan modal dalam menanam tanaman selanjutnya.

Penelitian yang dilakukan oleh Arisson, ${ }^{4}$ Pinjamannya berbentuk ayam dengan bentuk perjanjian lisan tanpa ada bentuk perjanjian tertulis. Sehingga dalam praktek jual beli hutang ini seringkali membuat pedagang ayam mengalami kerugian yang sangat berdampak pada pendapatan dan kehidupan ekonomi pedagang ayam. Sedangkan dampak jual beli hutang terhadap kehidupan ekonomi pedagang ayam di kecamatan Kelayang menunjukan jawaban sangat berpengaruh karena akan berdampak pada penurunan pendapatan yang bisa menyebabkan kerugian pada pedagang ayam.

Salah satu perwujudan dari mu'amalah yang disyari'atkan oleh Islam adalah jualbeli. Jual-beli itu merupakan salah satu bentuk ibadah dalam mencari rezeki untuk memenuhi kebutuhan hidup tidak terlepas dari hubungan sosial. alam kehidupan bermasyarakat setiap orang memiliki kepentingan terhadap orang lain, sehingga menimbulkan hubungan antara hak dan kewajiban. Seperti halnya dalam hasil pertaninan di Desa Pahonjean seringkali menggunakan sistem titip, DP (down payment) didepan sehingga petani merasa tidak puas dengan hasil jualnya karena sudah menghutang di awal. Hasil panen para petani adalah mata pencharian pokok yang bertujuan untuk mensejahterakan lingkup keluarga.

Dalam kehidupan bermasyarakat setiap orang memiliki kepentingan terhadap orang lain, sehingga menimbulkan hubungan antara hak dan kewajiban. Setiap orang punya hak untuk diperhatikan oleh orang lain dan dalam waktu yang sama menuntut kewajibannya ditunaikan. Hubungan hak dan kewajiban itu diatur dalam kaidah-kaidah hukum dengan bertujuan untuk menghindari terjadinya bentrokan berbagai kepentingan. Kaidah-kaidah hukum yang mengatur hubungan hak dan kewajiban dalam kehidupan bermasyarakat itu disebut dengan Mu'amalah ${ }^{5}$

Fiqih muamalah adalah pengetahuan tentang hukum-hukum syariat yang praktis, yang diambil dari dalil-dalil yang terperinci yang berkaitan dengan segala perbuatan manusia yang semua hukum asalnya boleh. Salah satunya adalah yang menjelaskan tata cara perpindahan hak milik seseorang kepada orang lain, misalnya melalui jual beli atau al-ba'i. Dalam jual beli terdapat pertukaran benda yang satu dengan benda lain yang menjadi penggantinya. Akibat hukum dari jual beli adalah terjadinya perpindahan hak milik seseorang dengan orang lain atau dari penjual kepada pembeli.

\footnotetext{
${ }^{3}$ Hardianto Eko, "Skripsi: Pengambilan Keputusan Petani Di Dataran Tinggi Dieng: Meningkatkan Usaha Tani Carica” (Yogyakarta: Universitas Gadjah Mada, 2015).

${ }^{4}$ Arisson, "Praktek Jual Beli Hutang Pada Pedagang Ayam Di Kecamatan Kelayang Kabupaten Indragiri Hulu Ditinjau Dari Ekonomi Islam,” Hukum Islam XVI, no. 2 (2016), hlm. 209-213.

${ }^{5}$ Abdullah Hoedi and Beni Ahmad Saebani, Metode Penelitian Ekonomi Islam Muamalah (Bandung: Pustaka Setia, 2014).
} 
Terdapat dua istilah yang digunakan untuk menunjukkan hukum Islam, yaitu Syariah Islam dan Fiqih Islam. Di dalam buku buku hukum Islam berbahasa Inggris, Syariah Islam disebut Law, sedangkan fiqih Islam disebut Islamic jurisprudence. Di Indonesia, syariah Islam sering disebut dengan istilah hukum syari'at atau hukum syara', sedangkan fiqih Islam sering disebut dengan istilah hukum fiqih atau kadang-kadang disebut dengan fiqih Islam. ${ }^{6}$ Namun dalam perkembangan zaman dan semakin kompleksnya permasalahan manusia dalam memenuhi kebutuhannya sering terjadi ketidaksesuaian antara norma dan perilaku manusia. Seiring perubahan dalam masyarakat praktik bermuamalahpun juga mengalami perubahan sehingga permasalahan-permasalahan baru bermunculan. Seperti halnya praktik hutang piutang dalam pertanian yang telah menjadi adat istiadat ( $u r f$ '), di desa Pahonjean masih terjadinya sistem hutang piutang dalam jual beli hasil pertanian sebelum masa panen berlangsung. Dengan demikian, berhutang pada hakikatnya dimaksudkan untuk kepentingan sosial, baik berhutangnya karena untuk keperluan konsumtif maupun produktif. Hanya saja dalam kenyataan hidup seharihari banyak orang mempraktikkan hutang secara komersial, yakni mengambil keuntungan dari transaksi tersebut.

Penelitian ini penting dilakukan untuk menganalisis keterlibatan pedagang dan para petani sehingga menghasilkan keuntungan antara dua belah pihak. Studi ini mengambil latar sosial di masyarakat Desa Pahonjean Kecamatan Majenang Kabupaten Cilacap yang sebagian besar adalah petani dan menggantungkan penjualan hasil pertanian pada pedagang. Studi mengenai jual beli sistem hutang sudah beberapa kali dilakukan tetapi hal yang membedakan adalah pada studi studi sebelumnya lebih banyak mengkaji dari perspektif kelemahan petani. Sedangkan pada penelitian ini berusaha untuk memahami realitas baik dari sudut pandang petani dan pedagang dengan tujuan untuk mensejahterakan petani dari sisi Ekonomi Islam.

\section{B. METODE PENELITIAN}

Penelitian ini merupakan penelitian lapangan (field research), dengan menggunakan pendekatan kualitatif. Penelitian kualitatif merupakan salah satu prosedur penelitian yang menghasilkan data deskriptif berupa ucapan dari orang-orang yang diamati. Atau penelitian yang menggambarkan tentang suatu masalah kejadian. ${ }^{7}$ Dalam tulisan ini dimaksudkan untuk menggali suatu fakta, lalu memberikan penjelasan terkait berbagai realita yang ditemukan. Oleh karena itu, peneliti langsung mengamati peristiwa-peristiwa di lapangan yang berhubungan dengan Praktek Jual beli Secara Langsung. Setelah data terkumpul data lapangan maka selanjutnya menggunakan, mengolah dan menganalisis data yang dipergunakan dalam penelitian ini adalah Metode deduktif, yaitu metode penganalisaan yang mengolah data yang bersifat umum untuk kemudian menarik kesimpulan yang bersifat khusus.

\section{HASIL DAN PEMBAHASAN}

\section{Pelaksanaan Jual Beli di Desa Pahonjean}

Praktek jual beli hasil pertanian dengan sistem hutang di Desa Pahonjean Kecamatan

${ }^{6}$ M Cholil Nafis, Teori Hukum Ekonomi Islam (Jakarta: UI-Press, 2011), hlm. 19.

${ }^{7}$ A Muri Yusuf, Metodelogi Penelitian (Jakarta: Kencana, 2014), hlm. 238. 
Majenang, sebagian besar para petani dan penjual saling mengenal satu sama lain hal ini berdasarkan hasil wawancara dengan petani terkait dengan praktik jual beli yang ada di Desa Pahonjean Kecamatan Majenang.Cara melakukan jual beli sistem utang/cash di desa Pahonjean Menurut salah seorang petani yaitu Bahrun jual beli dengan sistem tersebut sangat mudah apalagi dengan sistem $c a s h /$ bayar langsung. Kita datang ketempat penjual atau pengepul tinggal kita meminta uang saja seperti itu biasanya saya seperti itu kepada penjual yang sudah kenal, jumlahnya tidak banyak juga sebagai uang muka juga seperti itu, toh dalam pelaksanaanya kegiatan sistem ini pembeli dan penjual sudah kenal dari lama, tidak mungkin baru kenal kemudian langsung melakukan kegiatan utang-piutang. Pembeli tidak perlu mencari barang karena padi sudah pasti akan didapat. Harga yang disepakati disesuaika apakah harga awal ataupun harga di akhir.

Muhafid sebagai tokoh agama dan Petani yang juga melaksanakan jual beli pertanian dengan jual beli sistem hutang menyampaikan "secara praktik jual beli pertanian sistem hutang ini sama seperti jual yang lainnya tetapi yang membedakan adalah kita biasanya punya rasa hutang budi untuk menjualkan hasil panen kita kepada penjual, tetapi kita juga merasa terbantu dengan jual beli sistem ini, harus pinter-pinter juga memilih pedagang yang jujur dan tetap bersaing dengan harga pedagang lain.

Proses pinjam-meninjam dimulai dengan peminjam datang ke pedagang kemudian meminjam uang terlebih dahulu contoh saya butuh uang satu juta rupiah untuk bayar uang semesteran anak dengan tempo sampai dengan datang masa panen. Negosiasi tentang harga dan jenis padi yang akan ditanam pasti akan mempengaruhi harga dan jumlah yang akan saya jual kepada pedagang. Hasil kesepakatan bersama menjadi komitmen bersama antara pemberi hutang dengan peminjam antara lain berkaitan dengan peminjam menjual kepada pedagang dengan rasa tanggung jawab, dalam konteks ini rukun dan syarat jual beli sudah terpenuhi. Kedua belah pihak juga sudah bisa menganalisis baik dan tidaknya konsep jual beli tersebut.

Sesuai paparan di atas terlihat jelas bahwa sesuai dengan praktik hutang piutang yang terjadi, setelah pihak peminjam menjelaskan maksud yang mau di inginkan pemberi pinjaman menjelaskan syarat-syarat dan ketentuan yang harus dijalankan dan disepakati bersama. Berdasarkan penuturan Penjual Padi/ Gabah dan para petani Desa Pahonjean, bahwa praktik jual beli Padi/ Gabah di Desa Pahonjean diterapkan sistem hutang (tidak cash). Latar belakangnya adalah melakukan jual-beli secara hutang (ditangguhkan pembayarannya) karena sekarang ini banyak kebutuhan petani yang mendesak sedangkan petani tidak memiliki uang tunai kecuali saat sudah masa panen.

Beberapa faktor utama lainya secara umum petani perkebunan Desa Pahonjean memilih berhutang dari pada Cash adalah sebagai berikut :

a. Hutang sudah menjadi tradisi/kebiasaan ('urf)

b. Karena terpaksa, tanpa hutang tidak akan mampu membeli kebutuhan Pokok

c. Petani mengandalkan hasil panen saja.

Berdasarkan hasil wawancara dengan Kaur Pemerintahan Desa Pahonjean dan Juga sebagai pedagang padi menjelaskan bahwa

sistem jual beli dengan sistem hutang terlebih dahulu di desa Pahonjean telah mengakar dan menjadi budaya (urf) karena banyak masyarakat yang mengaplikasikannya dalam muamalah ini. 


\section{Analisis Jual Beli Hasil Pertaninan Dengan Sistem Hutang}

Ditinjau dari perspektif hukum Islam, praktik jual beli Hasil penen sistem pembayaran ditanguhkan/ hutang di Desa Pahonjean adalah memenuhi syarat dan rukun dengan teori jual beli, khususnya mengenai syarat jual beli. Rukun jual beli terpenuhi, tetapi dengan sistem hutang perlu diperjelas kembali pembayaran hutang nya

Menurut fuqaha Hanafiyah terdapat empat macam syarat yang harus terpenuhi dalam jual beli: (1) syarat in'akad; (2) syarat shihhah; (3) syarat nafadz, dan (4) syarat luzum. Perincian masing-masing sebagaimana disampaikan berikut:

Syarat in'akad terdiri dari:

a. Yang berkenaan dengan 'aqid: harus cakap bertindak hukum.

b. Yang berkenaan dengan akadnya yaitu terkait adanya persesuaian antara ijab dan Kabul serta berlangsung dalam majlis akad.

c. Yang berkenaan dengan obyek jual-beli yaiut obyeknya ada, berupa mal mutaqawwim, milik sendiri, serta dapat diserah-terimakan ketika akad.

Syarat shihhah terbagi kedalam dua syarat yaitu syarat shihhah yang bersifat umum dan khusus. Syarat umum shihhah yaitu jual beli tersebut tidak mengandung salah satu dari enam unsur yang merusaknya diantaranya jihalah (ketidakjelasan), ikrah (paksaan), tauqit (pembatasan waktu), gharar (tipu-daya), dharar (aniaya) dan persyaratan yang merugikan pihak lain. Sedangkan syarat shihhah yang bersifat khusus antara lain berkaitan dengan Penyerahan dalam hal jual-beli benda bergerak, Kejelasan mengenai harga pokok dalam hal al-ba'i' al-murabahah, Terpenuhi sejumlah kriteria tertentu dalam hal bai'ul-salam, Tidak mengandung unsur riba dalam jual beli harta ribawi. Syarat Nafadz, yaitu ada dua yaitu Adanya unsur milkiyah atau wilayah dan bendanya yang diperjualkan tidak mengandung hak orang lain.Sedangkan syarat Luzum yakni tidak adanya hak khiyar yang memberikan pilihan kepada masing-masing pihak antara membatalkan atau meneruskan jual beli. ${ }^{8}$

Hutang piutang menurut Kamus Besar Bahasa Indonesia, yaitu uang yang dipinjamkan dari orang lain. Sedangkan piutang mempunyai arti uang yang dipinjamkan (dapat ditagih dari orang lain). ${ }^{9}$ Secara terminologi syara', ulama fiqh berbeda pendapat dalam mendefinisikannya. ${ }^{10}$, antara lain :

a. Menurut Hanafiyah

Hutang piutang adalah memiliki manfaat secara cuma-cuma.

b. Menurut Malikiyah

Hutang piutang adalah memiliki manfaat dalam waktu tertentu dengan tanpa imbalan.

c. Menurut Syafi'iyah

Hutang piutang adalah kebolehan mengambil manfaat dari seseorang yang membebaskannya, apa yang mungkin untuk dimanfaatkan serta tetap zat barangnya supaya dapat dikembalikan kepada pemiliknya.

d. Menurut Hanabilah

\footnotetext{
${ }^{8}$ Wahbah Al-Zuhaily, Al-Fiqh Al-Islamy Wa Adillatuh (Baitur: Dar al-Fkr, 1989), hlm. 149.

${ }^{9}$ Poerwadarminto, Kamus Besar Bahasa Indonesia (Jakarta: Balai Pustaka, 2003), hlm. 1136.

${ }^{10}$ Hendi Suhendi, Fiqh Muamalah (Jakarta: Rajawali Press, 2014), hlm. 91-92.
} 
Hutang piutang adalah kebolehan mengambil manfaat suatu zat barang tanpa imbalan dari peminjam atau yang lainnya.

e. Menurut Ibnu Rifeah

Hutang piutang adalah kebolehan mengambil manfaat suatu barang dengan halal serta tetap zatnya supaya dapat dikembalikan.

f. Menurut Al-Mawardi

Hutang piutang adalah memberikan manfaat-manfaat.

Ekonomi Islam merupakan kegiatan yang dilakukan oleh umat Islam yang sesuai dengan sistem Syari'ah ini juga memiliki prinsip dimana prinsip tersebut berdasarkan AlQur'an, yakni ${ }^{11}$ :

a. Prinsip Kebebasan (freedom, Alhuriyah), Al-Qur'an hak individu dan kelompok. Dalam hal ini antara lain:

1) Pengakuan dan penghormatan pada kekayaan pribadi. Al-Qur'an memberikan kebebasan penuh kepada siapa saja untuk melakukan transaksi dengan yang dikehendaki selagi itu tidak diluar batas Syari'ah.

2) Legalitas dagang,. Bahwa Allah menghalalkan jual beli dan mengharamkan riba, bisa dilakukan asal berdagang dengan cara yang jujur dan menguntungkan.

b. Prinsip keadilan/ persamaan, bahwa kegiatan ekonomi harus menimbulkan cinta kepada Allah, konsep ini diberikan untuk memberikan jaminan kepada manusia.

c. Prinsip akhlak yang baik, dalam ajaran Islam tauhid merupakan hal yang paling asasi dan esiesial. Ia tidak boleh terlepas sampai dalam jiwa keyakinan setiap insan muslim yang mengakui, bahwa ada Tuhan yang patut disembah kecuali Allah semata dan Muhammad itu utusan -Nya. Prinsip tauhid ini secara Tauhid secara definitif telah dijabarkan oleh Allah

Dalam konteks keadilan sosial ekonomi ini, menurut konsep The Principle Of Fair Equality Of Oppurtunity John Rwls, pihak yang kurang mampu diberi peluang untuk mencapai prospek kesejahteraan, pendapatan dan otoritas. Mereka inilah yang harus diberi perlindungan khusus (Prioritas). Menurutnya, konsekwensi dari kehidupan bersosial adalah keharusan berkurban demi kepentingan umum. Tetapi tidak dapat dibenarkan bahwa pengorbanan ini diminta dari orang-orang yang kurang mampu untuk kelompok pemodal. Lebih lanjut John Rawls menegaskan bahwa program penegakan keadilan yang berdimensi kerakyatan haruslah memperhatikan dua prinsip keadilan. Pertama, memberi hak dan kesempatan yang sama atas kebebasan dasar yang paling luas seluas kebebasan yang sama bagi setiap orang. Kedua, mengatur kesenjangan sosial ekonomi yang terjadi sehingga dapat memberi keuntungan timbal balik (reciprocal benefits) bagi setiap orang, baik mereka yang berasal dari kelompok beruntung maupun tidak beruntung. ${ }^{12}$

Adapaun hikmah yang dapat diambil dari akad tersebut adalah: Adanya rasa saling tolong-menolong atau saling membutuhkan antarapihak-pihak yang bekerjasama. Dapat menambah atau meningkatkan penghasilan atau ekonomi petani penggarap maupun pemilik

\footnotetext{
${ }^{11}$ Mustaq Ahmad, Etika Bisnis Dalam Islam (Jakarta: Al-Kautsar, 2005), hlm. 93-95.

${ }^{12}$ Jhon Rawls, Teori Keadilan, ed. Uzair Fauzan and Heru Prasetyo (Yogyakarta: Pustaka Pelajar,

2006).
} 
tanah. Dapat mengurangi pengangguran. Meningkatkan produksi pertanian dalam negeri. Dapat mendorong pengembangan sektor riel yang menopong pertumbuhan ekonomi secara makro. $^{13}$

Praktik Jual beli hasil pertanian sesuai dengan hukum Islam dan prinsip Ekonomi Islam, antar kedua belah pihak pedagang dan petani saling bersepakat dan saling ridha, artinya kedua belah pihak sudah melakukannya dengan dasar suka sama suka (antaradin). Pedagang dan petani sama-sama saling mendapatkan keuntungan. Petani merasa terbantu untuk pemenuhan kebutuhan sehari-hari sedangkan pedagang terbantu dengan stok barang daganganya yang agar kebutuhan pelanggan selalu tersedia. Bila ditelisik lebih jauh posisi yang dialami oleh petani dalam hubungan sosial tersebut petani mempunyai kekuasan penuh dalam memilih pedagang yang akan dimintai hutang tetapi kelemahanya petani tidak mempunyai kekuatan dalam menentukan harga pasaran karena keterbatasan akses petani terhadap harga dipasaran.

\section{Analisis Kesejahteraan Petani di Desa Pahonjean}

Kesejahteraan berasal dari kata sejahtera yang berarti aman, sentosa, makmur dan selamat. ${ }^{14}$ atau dapat diartikan sebagai kata atau ungkapan yang menunjuk kepada keadaan yang baik, atau suatu kondisi dimana orang-orang yang terlibat di dalamnya berada dalam keadaan sehat, damai dan makmur. Dalam arti yang lebih luas kesejahteraan adalah terbebasnya seseorang dari jeratan kemiskinan, kebodohan dan rasa takut sehingga dia memperoleh kehidupan yang aman dan tenteram secara lahiriah maupun batiniah

Chapra menggambarkan secara jelas bagaimana eratnya hubungan antara Syariat Islam dengan kemaslahatan. Ekonomi Islam yang merupakan salah satu bagian dari Syariat Islam, tentu mempunyai tujuan yang tidak lepas dari tujuan utama Syariat Islam. Tujuan utama ekonomi Islam adalah merealisasikan tujuan manusia untuk mencapai kebahagiaan dunia dan akhirat (falah), serta kehidupan yang baik dan terhormat (al-hayah al-thayyibah). Ini merupakan definisi kesejahteraan dalam pandangan Islam, yang tentu saja berbeda secara mendasar dengan pengertian kesejahteraan dalam ekonomi konvensional yang sekuler dan materialistic. $^{15}$

Di antara tujuan diselenggarakannya kesejahteraan sosial adalah Pertama, meningkatkan taraf kesejahteraan, kualitas, dan kelangsungan hidup. Kedua, memulihkan fungsi sosial dalam rangka mencapai kemandirian. Ketiga, meningkatkan ketahanan sosial masyarakat dalam mencegah dan menangani masalah kesejahteraan social. Keempat, meningkatkan kemampuan, kepedulian dan tanggungjawab sosial dunia usaha dalam penyelenggaraan kesejahteraan sosial secara melembaga dan berkelanjutan. Kelima, meningkatkan kemampuan dan kepedulian masyarakat dalam penyelenggaraan kesejahteraan sosial secara melembaga dan berkelanjutan. Keenam, meningkatkan kualitas manajemen penyelenggaraan kesejahteraan sosial.

\footnotetext{
${ }^{13}$ Muhammad Ngasifudin, “Aplikasi Muzara'ah Dalam Perbankan Syariah,” Jurnal Ekonomi Syariah Indonesia VI, No. 1 (2016), hlm. 38-44,.

${ }^{14}$ Poerwadarminto, Kamus Besar Bahasa Indonesia. hlm. 889

${ }^{15}$ Umer Chapra, Masa Depan Ilmu Ekonomi (Sebuah Tinjauan Islam) (Jakarta: Gema Insani Press,

2001).
} 
Indikator kesejahteraan Islami adalah terpenuhinya kebutuhan fisik dari rizqi yang halal, hidup sehat secarajasmani dan rohani, keberkahan rizki yang diterima, keluarga yang sakinahmawaddah wa rahmah, rasa cintakasih sesama, ridha dan qana'ah dengan apa yang diberikan Allah kepadanya serta merasa bahagia ${ }^{16}$. Kesejahteraan ekonomi merupakan suatu kondisi dan tata kehidupan sosial ekonomi yang sejahtera, yaitu yang memungkinkan setiap orang, kelompok atau masyarakat untuk memenuhi kebutuhan jasmaniah dan rohaniah yang dikenal sebagai dasar manusia dengan sebaik-baiknya, dalam pandangan islam kesejahteraan disebut dengan falah tidak hanya didunia tetapi juga diakhirat sebgai tujuan terakhir, sehingga didunia tercapai kebutuah sandang, pangan, papan. Untuk mencapai kesejahteraan maka diperlukan sebuah usaha yang harus dilakukan oleh manusia, bahkan diwajibkan untuk bekerja keras demi memenuhi kebutuhan hidup individu juga keluarga. hal ini juga ada didalam Al-Quran Surat Toha 132 sebgai peritah kepada manusia untuk bekerja keras.

Kesejahteraan seseorang akan terpenuhi jika kebutuhan mereka tercukupi, kesejahteraan sendiri mempunyai beberapa aspek yang menjadi indikatornya, di mana salah satunya adalah terpenuhinya kebutuhan seseorang yang bersifat materi, kesejahteraan yang oleh Al-ghazali dikenal dengan istilah (al-mashlahah) yang diharapkan oleh manusia tidak bisa dipisahkan dengan unsur harta, karena harta merupakan salah satu unsur utama dalam memenuhi kebutuhan pokok, yaitu sandang, pangan dan papan ${ }^{17}$

Maslahat sebagai substansi dari maqashid al-syari'ah dapat dibagi sesuai dengan tinjauannya. Bila dilihat dari aspek pengaruhnya dalam kehidupan manusia, maslahat dapat dibagi menjadi tiga tingkatan ${ }^{18}$ :

a. Dharuriyat, yaitu maslahat yang bersifat primer, di mana kehidupan manusia sangat tergantung padanya, baik aspek diniyah (agama) maupun aspek duniawi. Maka ini merupakan sesuatu yang tidak dapat ditinggalkan dalam kehidupan manusia. Jika itu tidak ada, kehidupan manusia di dunia menjadi hancur dan kehidupan akhirat menjadi rusak (mendapat siksa). Ini merupakan tingkatan maslahat yang paling tinggi. Di dalam Islam, maslahat dharuriyat ini dijaga dari dua sisi: pertama, realisasi dan perwujudannya, dan kedua, memelihara kelestariannya. Contohnya, yang pertama menjaga agama dengan merealisasikan dan melaksanakan segala kewajiban agama, serta yang kedua menjaga kelestarian agama dengan berjuang dan berjihad terhadap musuh-musuh Islam.

b. Hajiyat, yaitu maslahat yang bersifat sekunder, yang diperlukan oleh manusia untuk mempermudah dalam kehidupan dan menghilangkan kesulitan maupun kesempitan. Jika ia tidak ada, akan terjadi kesulitan dan kesempitan yang implikasinya tidak sampai merusak kehidupan.

c. Tahsiniyat, yaitu maslahat yang merupakan tuntutan muru'ah (moral), dan itu dimaksudkan untuk kebaikan dan kemuliaan. Jika ia tidak ada, maka tidak sampai merusak ataupun menyulitkan kehidupan manusia. Maslahat tahsiniyat ini diperlukan sebagai kebutuhan tersier untuk meningkatkan kualitas kehidupan manusia

${ }^{16}$ Pusat Pengkajian dan Pengembangan Ekonomi Islam UII, Ekonomi Islam (Jakarta: PT. Raja Grafindo, 2008), hlm. 1-13.

${ }^{17}$ Adiwarman Azwar Karim, Sejarah Pemikiran Ekonomi Islam (Jakarta: Raja Grafindo Persada, 2008).

${ }^{18}$ Al-Zuhaily, Al-Fiqh Al-Islamy Wa Adillatuh. hlm. 1020. 
Berikut adalah data yang diperoleh dari hasil penelitian terkait kesejahteraan petani:

Tabel 1. Tingkat Rumah Para Petani

\begin{tabular}{|l|l|l|}
\hline NO & Indikator & Data tahun 2020 \\
\hline 1 & Kepemilikan rumah & HAK MILIK \\
\hline 2 & Jumlah KK responden & 64 \\
\hline 3 & Rumah Dengan kualitas baik & $87.5 \%$ \\
\hline 4 & Rumah dengan kualitas Sedang & $6.25 \%$ \\
\hline 5 & Rumah Dengan kualitas Rendah & $6.25 \%$ \\
\hline 7 & Memiliki sumber LISTRIK dari PLN & $100 \%$ \\
\hline 8 & Memiliki Air dan MCK yang baik & $93.75 \%$ \\
\hline
\end{tabular}

Sumber: Data diolah, 2020

Tabel 2. Berdasarkan hasil penelitian indikator BKKBN

\begin{tabular}{|c|c|c|}
\hline NO & INDIKATOR & PROSENTASE \\
\hline 1 & Anda mempunyai tempat tinggal & $100 \%$ \\
\hline 2 & $\begin{array}{l}\text { Semua anggota keluarga makan setiap } \\
\text { hari }\end{array}$ & $100 \%$ \\
\hline 3 & Anggota keluarga makan 2 kali sehari & $100 \%$ \\
\hline 4 & $\begin{array}{l}\text { Semua anggota keluarga memiliki } \\
\text { pakaian yang berbeda dalam beraktivitas }\end{array}$ & $100 \%$ \\
\hline 5 & $\begin{array}{l}\text { Rumah tempat tinggal memiliki atap, } \\
\text { dinding dan lantai }\end{array}$ & $96,8 \%$ \\
\hline 6 & $\begin{array}{l}\text { Jika ada anggota keluarga sakit berobat } \\
\text { di sarana kesehatan }\end{array}$ & $93,75 \%$ \\
\hline 7 & Semua anggota keluarga beribadah & $90,63 \%$ \\
\hline 8 & $\begin{array}{lll}\text { Makan } & \text { daging/telur/ikan } & \text { dalam } \\
\text { seminggu }\end{array}$ & $96,87 \%$ \\
\hline 9 & Membeli pakaian minimal setahun sekali & $100 \%$ \\
\hline 10 & $\begin{array}{l}\text { Lantai rumah berukuran } 8 \mathrm{~m} 2 \text { untuk } \\
\text { setiap anggota keluarga }\end{array}$ & $100 \%$ \\
\hline 11 & $\begin{array}{l}\text { Dalam keadaan sehat selama } 3 \text { bulan } \\
\text { terakhir }\end{array}$ & $100 \%$ \\
\hline 12 & $\begin{array}{l}\text { Ada salah seorang diantara anggota } \\
\text { keluarga yang bekerja mendapatkan } \\
\text { penghasilan }\end{array}$ & $60,9 \%$ \\
\hline 13 & $\begin{array}{l}\text { Ada anggota keluarga usia } 10 \mathrm{~s} / \mathrm{d} 60 \\
\text { tahun yang buta aksara }\end{array}$ & $0 \%$ \\
\hline 14 & $\begin{array}{l}\text { Di keluarga anda mengikuti pengajian } \\
\text { agama }\end{array}$ & $89,6 \%$ \\
\hline 15 & $\begin{array}{l}\text { Sebagian hasil pendapatan keluarga anda } \\
\text { ditabung }\end{array}$ & $40,6 \%$ \\
\hline 16 & $\begin{array}{l}\text { Keluarga anda membiasakan diri makan } \\
\text { bersama dirumah }\end{array}$ & $98,4 \%$ \\
\hline
\end{tabular}




\begin{tabular}{|l|l|l|}
\hline 17 & Mempunyai televisi/radio & $100 \%$ \\
\hline 18 & $\begin{array}{l}\text { Anda secara tertatur memberikan } \\
\text { sumbangan social/ Zakat }\end{array}$ & $67,2 \%$ \\
\hline
\end{tabular}

Sumber: Data diolah, 2020

Tabel 3. Tingkat Kesejahteraan Petani

\begin{tabular}{|l|l|l|l|}
\hline NO & Kesejahteraan Menurut Pandangan Ekonomi Islam & Jumlah KK & Prosentase \\
\hline 1 & Daruriyat & 8 & $12,5 \%$ \\
\hline 2 & Hajiyat & 54 & $84,375 \%$ \\
\hline 3 & Tahsiniyat & 2 & $3,125 \%$ \\
\hline Jumlah & $\mathbf{6 4}$ & $\mathbf{1 0 0 \%}$ \\
\hline
\end{tabular}

Sumber: Data diolah, 2020

Dengan data di atas jelaslah bahwa taraf kesejahteraan ekonomi Desa Pahonjean, di dalam Islam ekonomi Islam hanya sampai pada taraf pemenuhan kesejahteraan dharuriyat (primer) dan hajiyat (skunder) saja, sedangkan penyempurnaan kebutuhan hajiyat (tersier) belum terpenuhi dengan baik. Oleh karenanya, dengan adanya pengelolaan Panen padi yang baik dalam hal ini adalah proses dari tanam sampai panen bisa dikelola dengan baik tentunya bisa meningkatkan kesejahteraan para petani sehingga kebutuhan tersier iru bisa terpenuhi dengan baik.

Menjaga jiwa dari segi keberadaannya (min nahiyat al-wujud) yaitu dengan memberi nutrisi berupa makanan dan minuman; dan menjaga jiwa dari segi segi ketidakadaannya (min nahiyat al-'adam) menjalankan sanksi qisas dan diyat terhadap pidana pembunuhan. Dengan demikian seorang muslim dalam memenuhi kebutuhan rumah tangganya atau seluruh proses aktivitas ekonomi di dalamnya, dengan demikian seorang muslim dalam memenuhi kebutuhan rumah tangganya atau seluruh proses aktivitas ekonomi di dalamnya, harus dilandasi legalitas halal-haram, mulai dari produktivitas atau kerja, hak kepemilikan, konsumsi atau pembelanjaan, transaksi dan investasi. ${ }^{19}$

\section{KESIMPULAN}

Jual beli dengan sistem hutang terlebih dahulu di desa Pahonjean telah mengakar dan menjadi budaya (urf) karena menunggu panen dibutuhkan waktu kurang lebih tiga/empat bulan. Dan para petani hanya mengandalkan sawahnya sebagai mata pencarian utamanya. Ditinjau dari perspektif hukum Islam, praktik jual beli hasil panen sistem pembayaran ditanguhkan di Desa Pahonjean adalah memenuhi syarat dan rukun dengan teori jual beli, khususnya mengenai syarat jual beli. Rukun jual beli sudah terpenuhi, tetapi dengan sistem hutang perlu diperjelas kembali pembayaran hutangnya karena memang belum ada kejelasan dalam pengembalian hutang.

Dilihat dari data-data yang telah di sajikan terdapat beberapa indikasi yang menunjukan kesejahteraan masyarakat Pahonjean dengan mata pencarian sebagai petani adalah tergolong rendah. Sedangkan Kesejahteraan ekonomi Desa Pahonjean, di dalam Islam ekonomi

${ }^{19}$ Mustafa Edwin Nasution, M. Arief Mufraeni, and dkk, Pengenalan Eksklusif Ekonomi Islam (Jakarta: Kencana Prenada Media Group, 2007), hlm. 123. 
Islam hanya sampai pada taraf pemenuhan kesejahteraan dharuriyat (primer) dan hajiyat (skunder) saja.

\section{E. DAFTAR PUSTAKA}

Ahmad, Mustaq. Etika Bisnis Dalam Islam. Jakarta: Al-Kautsar, 2005.

Al-uhaily, Wahbah. Al-Fiqh Al-Islamy Wa Adillatuh. Baitur: Dar al-Fkr, 1989.

Arisson. "Praktek Jual Beli Hutang Pada Pedagang Ayam Di Kecamatan Kelayang Kabupaten Indragiri Hulu Ditinjau Dari Ekonomi Islam.” Hukum Islam XVI, no. 2 (2016).

Chapra, Umer. Masa Depan Ilmu Ekonomi (Sebuah Tinjauan Islam). Jakarta: Gema Insani Press, 2001.

Eko, Hardianto. "Skripsi: Pengambilan Keputusan Petani Di Dataran Tinggi Dieng: Meningkatkan Usaha Tani Carica."Yogyakarta: Universitas Gadjah Mada, 2015.

Hoedi, Abdullah, and Beni Ahmad Saebani. Metode Penelitian Ekonomi Islam Muamalah. Bandung: Pustaka Setia, 2014.

Karim, Adiwarman Azwar. Sejarah Pemikiran Ekonomi Islam. Jakarta: Raja Grafindo Persada, 2008.

Lusiana Ulfa, Hardinawati. “Alasan Petani Muslim Menjual Hasil Panen Kepada Tengkulak Di Desa Glagahagung Kecamatan Purwoharjo Kabupaten Banyuwangi." Skripsi: Surabaya: Universitas Airlangga, 2017.

Muri Yusuf, A. Metodelogi Penelitian. Jakarta: Kencana, 2014.

Nafis, M Cholil. Teori Hukum Ekonomi Islam. Jakarta: UI-Press, 2011.

Nasution, Mustafa Edwin, M. Arief Mufraeni, and Dkk. Pengenalan Eksklusif Ekonomi Islam. Jakarta: Kencana Prenada Media Group, 2007.

Ngasifudin, Muhammad. "Aplikasi Muzara'ah Dalam Perbankan Syariah.” Jurnal Ekonomi Syariah Indonesia VI, No. 1 (2016).

Poerwadarminto. Kamus Besar Bahasa Indonesia. Jakarta: Balai Pustaka, 2003.

Pusat Pengkajian dan Pengembangan Ekonomi Islam UII. Ekonomi Islam. Jakarta: PT. Raja Grafindo, 2008.

Rawls, Jhon. Teori Keadilan. Edited by Uzair Fauzan and Heru Prasetyo. Yogyakarta: Pustaka Pelajar, 2006.

Suhendi, Hendi. Fiqh Muamalah. Jakarta: Rajawali Press, 2014.

Syafa'at, Abdul Kholiq, and Rohmatulloh. "Analisis Hukum Islam Terhadap Praktik Jual Beli Hasil Pertanian Padi Sistem Tebasan Di Dusun Kelir Desa Bunder Kecamatan Kabat Kabupaten Banyuwangi." Jurnal Darussalam; Jurnal Pendidikan, Komunikasi dan Pemikiran Hukum Islam X, no. 1 (2018). 